\title{
Pohled na vývoj hodnocení výkonu při lezení na pískovcových skalách České křídové tabule
}

\author{
Insight into the performance evaluation of sandstone climbing \\ in the Czech Cretaceous
}

\author{
Ladislav Vomáčko \\ Univerzita Karlova, Fakulta tělesné výchovy a sportu
}

\begin{abstract}
Abstrakt
Vývoj hodnocení výkonu v pískovcovém horolezectví je spjat z rozvojem lezení na pískovcích rozprostírajících se v České křídové tabuli a v německém Sasku. Článek přispívá k vytvoření obrazu o vývoji lezení na našich pískovcových skalách, s prihlédnutím k socioekonomické situaci a vlivu sudetských nèmeckých lezců. V krátkosti se zabývá pravidly lezení na pískovcových skalách, která byla stanovena a ústně tradována od počátku dvacátého století a s určitými změnami platí dodnes. Přispěvek dále dokumentuje vývoj hodnocenív různých oblastech pískovcového lezení, poukazuje na dưležité milníky pískovcového horolezectví a vysvětluje stagnaci nárůstu lezecké výkonnosti pískovcového horolezectví od roku 1945 do roku 1990. Dále nabízí srovnání hodnocení výkonů na různých typech skal včetně lokálních odlišností a upozorňuje na silnou subjektivitu v hodnocení.
\end{abstract}

Klíčová slova: Český ráj, horolezectví, lezecké stupnice, tradiční lezení

\begin{abstract}
The development of performance evaluation in sandstone climbing is linked to the development of climbing on sandstone rocks in the Czech Cretaceous basin and in the German Saxony. This paper describes the development of climbing performance on the Czech sandstone in the context of the given socio-economic situation and the influence of the Sudetenland German climbers. It provides a short overview of the rules of sandstone climbing that were set at the beginning of the $20^{\text {th }}$ century and are applied with certain modifications until today. This paper follows the development of performance evaluation in several different sandstone areas, pinpoints the milestones of sandstone climbing and explains the performance stagnation in sandstone climbing in the postwar period and further until 1990. It compares the performance evaluation on different kinds of stone taking into consideration the local particularities of the evaluation and draws the attention to its high subjectivity of the evaluation.
\end{abstract}

Key words: Czech paradise, mountaneering, climbing grade, trad climbing

Pískovcové lezení je v české kotlině a přilehlém Sasku samostatnou disciplínou na pomezí lezení a horolezectví. Díky dodržování historických pravidel lezení a ctění tradic můžeme tvrdit, že „pískařeni“ má blíže k horolezectví se všemi svými aspekty. Při tomto způsobu lezení je nutné sladit psychickou odolnost, fyzickou připravenost a technické dovednosti k přelezení vybraných cest.

První zmínky o začátcích lezení na pískovcích můžeme zachytit na počátku 19. století, kde je zdokumentován výstup Hankeho na Mönch 19. 3. 1803. V průběhu 19. století byla lezecká aktivita spíše sporadická, i když lze nalézti výstupy komíny a různými žlaby. Kolébkou pískovcového lezení je Sasko, kde se nachází asi největší a nejzajímavější pískovcové věže. Postupně se lezení rozširíilo do přilehlých oblastí a poté hlouběji do Čech. 
Již na počátku dvacátého století, kdy se začalo rozvijet pískovcové lezení, bylo snahou průkopníků volného lezení dosáhnout vrcholu pouze vlastní silou. Volný způsob lezení vycházel z etiky a jeho kořeny lze hledat ve vztahu $\mathrm{k}$ př́rodě, sportovní cti a v neposlední řadě ze skutečného lezení. Průkopníkem zavádění pravidel pískovcového lezení byl Dr. Rudolf Ferhmann. Ten započal svou lezeckou kariéru v roce 1903 výstupem na neznámou pískovcovou věž v Sasku. Rok nato 3. 6. 1904 založil se svými druhy lezecký klub Schwarze Kamin (Černý komín). Názory na čistotu lezení přejímal Ferhmann od mladého P. Preusse, který zastával názor, že lezec musí být schopný přelézt jakékoliv místo bez lana a beze skob. První pravidla neměla psanou formu a předávala se pouze ústně. Díky malému počtu lezců v celé lezecké komunitě byla pravidla respektována. První písemná pravidla pocházela z německého Saska. Jejich autorem byl Rudolf Fehrmann, který je vydal $\mathrm{v}$ dodatku $\mathrm{k}$ lezeckému průvodci $\mathrm{v}$ roce 1913. Tímto počinem byla ustanovena pravidla pro lezení na pískovcích, která $\mathrm{v}$ základní formě platí do dnešní doby.

Česky psaná pravidla byla vydána až o několik desetiletí později. V roce 1939 se R. O. Bauše v časopise Horolezec zamýšlí nad problémem pravidel lezení na pískovcích: „Němečtí lezci mají dlouhou tradici v horolezectví. My Češi ji teprve tvoříme. Myslím, že bude na místě, když uvedu několik zásad atd.“,

V průvodci R. O. Baušeho z roku 1948 je informace o etice výstupů ,... jest prvním a základním zákonem lezeckým, že věž může býti zlezena jedině vlastní silou a obratností lezce bez použití umělých pomůcek“(Bauše,1948; str. 7). Bauše také ve svém průvodci apeluje na svědomí lezců k dodržování lezecké etiky. První písemná česká verze lezeckých pravidel se objevuje až v Jedličkově průvodci „Po pískovcových skalách“ vydaném v roce 1961. Horolezecká sekce ÚV ČSTV vydala 28. 3. 1968 rozšířené znění pravidel, ve kterých bylo napsáno: „...lézt pouze vlastní silou, $k$ jištění využívat jen prírodních útvario. Jako jistící pomůcky lze použí smyčky z lan nebo popruhů, které se uzly vkládaji do spár a trhlin, poprípadě se upevnuují kolem hrotů a výčnělkủ. Veškeré jištění se musí provádèt tak, aby nenarušovalo měkký pískovec. Pokud se při výstupu vyskytne místo obtizzně zajistitelné výše uvedenými standardními jistícimi prostředky, je možno v tomto mistě osadit skobu s kruhem, a to natrvalo. Kruh by se měl ve skále osazovat pod těžkým krokem, nikoli v něm, popr. nad ním. Umístění a osazení těchto kruhů prísluši pouze prvovýstupci, každá nová cesta je tvořena způsobem od spodu nahoru, přirozený povrch skály nesmí být dotčen lidským zásahem (např́klad lezením za mokra nebo lezením s použitím magnézia)... ". V zásadě jsou tato pravidla platná do dnešní doby pro tradiční lezecké oblasti, ale pod vlivem francouzského způsobu jištění jsou v některých oblastech porušována. Mezi předními horolezci minulé doby převládal názor, že čím „méně železa“ ve skále (osazené železné kruhy), tím je výstup hodnotnější. $V$ dnešní době při markantním nárůstu výkonnosti nelze s tímto pravidlem zcela souhlasit, protože by se výrazně zbrzdil vývoj v tvorbě extrémně obtížných cest.

S nárůstem výkonnosti se postupně měnily i styly výstupů na pískovcové vrcholy. Mladší generace lezců přelezly čistě cesty, ve kterých jejich předchůdci či prvovýstupci používali „stavění“ či boční jištění - tzv. schwebe, které zavedli němečtí lezci. Koncem padesátých a začátkem šedesátých let došlo k dalšímu skoku ve vývoji pískovcového horolezectví hledáním nových možností průstupů na nové věže. V oblasti Prachovských skal na tom mají zásluhu hlavně V. Krupička, Z. Kotátko a J. Havlík se svými spolulezci. Pod jejich vedením vzniklo mnoho nových cest převážně po východních a západních stěnách (Obelisk, Táborská, Kobyla, Jehla, Šikmá věž), z nichž velká část je prubířským kamenem pro dnešní lezce.

V sedmdesátých letech došlo ke změně v náhledu pískovcových lezců na způsob výstupu. Tuto změnu zapříčinili nepískovcoví skalní lezci, kteří považovali za hodnotné vylézt cestu bez odsedávání či dobírání v postupovém jištění. Do této doby se na písku odsedávalo či dobíralo skoro u každého fixního bodu postupového jištění. Základy moderního stylu přelézání cest lze nalézt v roce 1973, kdy německý lezec Kurt Albert navštívil pískovce v Sasku a myšlenku „pískařü“ dovedl k dokonalosti. Kurt Albert (Zak, 1996; str. 209) uvádí „...tehdy jsem poznal, že odpočivání 
u kruhů není správné, že by člověk měl zalézt celou lanovou délku. “Začal označovat cesty přelezené bez odpočívání v postupovém jištění či bez pádu červeným bodem. $\mathrm{Z}$ těchto činů se postupně vyvinuly jednotlivé styly přelezů (RP; AF; OS;).

Pískovcová skalní města Labské pískovce jsou unikátní geologicko-geomorfologické výtvory, které se rozprostírají v oblasti severozápadních Čech při hranicích s Německem, resp. Saskem. V pomyslném trojúhelníku mezi Mladou Boleslaví, Jičínem a Turnovem leží tzv. Český ráj a v severovýchodních Čechách v oblasti Broumovska. Další menší pískovcové oblasti jsou položeny v oblasti Kokořínska a Mšena. Uvedené oblasti však nedosahují takové významnosti. Všechna uvedená skalní města jsou součástí České křídové tabule.

Pískovcová skalní města jsou seskupením skalních tvarů (věží, bloků a stěn), vytvořená procesem zvětrávání a erozí různých typů hornin. Skalní města se vyskytují na vysoko položených plošinách, svědeckých vyvýšeninách, skalních hřebenech a údolních svazích. Vznik a vývoj skalních měst je dán různou odolností sedimentárně uložených hornin s přítomností puklin, ve kterých zprvu vznikají závrty a později zejména díky mechanickému zvětrávání (převážně kryogennímu) se na další modelaci terénu podílejí gravitační pohyby, fluviální a eolická eroze (Rubín \& Balatka, 1986).

Z hlediska sociálně geografického je nutné podotknout, že skalní města České křídové tabule se nachází v tzv. Sudetech, kde žila převážně německá menšina. V době habsburské monarchie dosídlilo německé obyvatelstvo příhraniční oblasti České kotliny. Po pádu Bachova absolutismu můžeme sledovat rozvoj spolkové činnosti jak německého, tak českého obyvatelstva. Spolky se zaměřovaly na kulturní i sportovní aktivity. Do tohoto období můžeme datovat vznik turistiky, která postupně zavedla návštěvníky do hor a byla jednou z podmínek pro vznik „alpských“ spolků. Lezení na pískovcových skalách bylo vyústěním pohybu turistů $v$ uvedených oblastech převážně v oblasti Českého ráje.

Nutno podotknout, že první pokusy o zdolání pískovcových věží jsou zdokumentované v Saském Rathenu v roce 1888. Mohutný rozvoj lezeckých aktivit je zásluhou právě Němců žijících v Liberci (Reichenbergu). Hlavním protagonistou rozvoje lezení v Jizerských horách a na pískovcích byl Rudolf Kauschka, který již v roce 1906 vylezl výraznou spárou legendární cestu na Dračí zub s obtížností VII (Kittler 2008). Tímto výkonem posunul mez obtížnosti na dvě desetiletí dopředu. Češi o rok později podnikají první vážné pokusy př̀i výstupech v Prachovských skalách pod vedením Josefa Kubína a Josefa Hendrycha. V roce 1907 zakládají neoficiální první český lezecký spolek - Lezecký kroužek Prachov.

Soutěživost mezi českými a německými lezci dosahuje vrcholu v druhé polovině třicátých let při výstupu na impozantní skalní věž Kobyla, kde je v dnešní době několik lezeckých cest, $\mathrm{z}$ nichž Německá a Česká cesta jsou odkazem někdejšího zápolení. Vznikly rok po sobě a patří k velmi obtížným výstupům i v dnešní době. Rozvoj pískaření zbrzdila druhá světová válka, kdy mnoho německých lezců bylo povoláno do wehrmachtu. $V$ době války působí čeští lezci převážně v oblasti Hruboskalska v čele s Josefem Smítkou, který byl ke konci války popraven gestapem.

\section{PODMÍNKY LEZENÍ V OBDOBÍ 1948-1990}

Po skončení druhé světové války byla obnovena spolková činnost a v roce 1946 ustanoven Svaz československých horolezců, který byl postupně přeměněn v roce 1957 na Horolezeckou sekci ČSTV. V době „socialistického“ Československa se nepreferovalo lezení na pískovcových skalách jako samostatná disciplína, ale lezení na skalách se považovalo za př́pravu na horolezecké aktivity ve velehorách. Protagonistou tohoto směru by Radan Kuchař, který prohlásil, že Skalák musí mít nějaké logické pokračování v Tatrách, Kavkaze, Alpách. Tento směr se ukázal jako ne 
úplně správný, protože v lezení na pískách lze pokračovat výstupy v německém Sasku, kde jsou skalní věže a masívy vyšší.

S ohledem na tento fakt a vazby na Sovětský svaz bylo nutné demonstrovat sílu socialistického bloku hrdinnými výstupy ve velehorách. Pro rozvoj výkonnosti mladých horolezců měl socialistický systém pochopení a díky oddílu TJ Uranové doly Hamr se podařilo uskutečnit mnoho zajímavých výprav do evropských i vzdálených velehor (Šmíd 1991). Ostatní horolezci s ohledem na náklady spojené s realizací různých výprav byli zaměstnáváni jako výškoví specialisté.

\section{VÝVOJ PÍSKOVCOVÉ KLASIFIKACE}

Hodnocení výkonu v horolezectví nebo v pískaření s sebou přináší mnoho problémů a diskuse o hodnocení se objevují již od zavedení stupnic obtížnosti přelezů. Klasifikace obtížností informuje a vyjadřuje fyzickou a psychickou námahu, kterou je nutno vynaložit $\mathrm{k}$ překonání lezeckého místa. Jde převážně o subjektivní pocity, které mají co nejpřesněji vyjádřit objektivní skutečnosti (Koller 1977). Objektivní faktory určují obtížnost lezeckého místa jako je velikost a tvar chytů, sklon skály, struktura, apod. Tyto faktory ale neumožňují objektivní hodnocení obtížnosti.

Lezení na písku má v Sasku a Čechách obrovský význam a velmi bohatou tradici. Od roku 1923 se používala sedmimístná stupnice (I-VII), kterou zavedl v průvodci R. Fehrmann (Šajnoha, 1990). Stupnice se pohybovala v rozmezí od lehkých cest (stupeň I) až po cesty krajně obtížné (stupeň VII).

Velmi zajímavou kapitolou hodnocení výkonu na pískovcových skalách byla Janebova klasifikační stupnice, tzv. „Janebovka“, která platila v Prachovských skalách až do roku 1959. Janeba klasifikoval pěti stupni (od I do V). Stupeň I symbolizuje nejlehčí obtížnost, stupeň V nejvyšší obtížnost cesty. Vzájemným porovnáním obtížnosti jednotlivých cest určoval další stupně. Vycházel z již značených cest se stupněm I až V a snažil se nalézt několik středně obtížných výstupů, s kterými ty další porovnával:

a) přibližně stejné obtíže - označení stupněm obtížnosti III;

b) obtížnější (než III), ale snadnější než známé výstupy očíslované stupněm obtížnosti V - označení stupněm obtížnosti IV (výstupy těžké);

c) snadnější (než III), ale obtížnější než známé výstupy očíslované stupněm I - označení stupněm obtížnosti II.

Celá Janebova stupnice zahrnovala:

obtížnost I - snadné výstupy;

obtížnost II - mírně těžké výstupy;

obtížnost III - středně těžké výstupy;

obtížnost IV - těžké výstupy;

obtížnost V - velmi těžké výstupy.

Janeba také upozorñoval na relativnost stupnice a poukazoval například na situaci, kdy lezec absolvuje cestu velmi obtížnou a následovně leze cestu středně těžkou, jejíž obtížnost se mu zdá (v porovnání s cestou předcházející) výrazně jednodušší. Pro zohlednění momentálního psychického stavu a délky lezecké praxe, a také pro upřesnění stupnice použil následující pohyblivou stupnici: 
Tab. 1: Janebova pohyblivá stupnice

\begin{tabular}{|l|c|c|c|}
\hline & A & B & C \\
\hline stupeň obtížnosti I & velmi snadné & snadné & mírně těžké \\
\hline stupeň obtížnosti II & snadné & mírně těžké & středně těžké \\
\hline stupeň obtížnosti III & mírně těžké & středně těžké & těžké \\
\hline stupeň obtížnosti IV & středně těžké & těžké & velmi těžké \\
\hline stupeň obtížnosti V & těžké & velmi těžké & nesmírně těžké \\
\hline
\end{tabular}

Stupnice A je pro lezce, kterým nedělá problém žádný výstup, jsou nadaní a dobře vyškolení; lezci jsou v dobré kondici a podnikají výstup za přiznivých okolností.

Stupnice B vyjadřuje obtížnost výstupů všem zdatným a dobře školeným lezcům; jsou-li tito lezci indisponováni nebo lezou za nepř́iznivých podmínek, určuji si obtížnost výstupu dle stupnice $\mathrm{C}$, ale nemají-li svůj den, mohou použít stupnici A.

Stupnice $\mathbf{C}$ vyjadřuje obtížnost výstupů všem průměrným nebo málo školeným lezcům; lezou-li tito lezci za nepřiznivých podmínek, stává se výstup o stupeň těžším.

Janebova stupnice byla velmi důmyslná, určitým způsobem nadčasová a svým dalším rozdělením připomíná současnou stupnici používanou na Britských ostrovech. Zrušena byla v roce 1959, kdy byly doplněny dva stupně, tak aby byla shodná se stupnicí z Hruboskalska a dalších oblastí. V návaznosti na to byl v roce 1961 vydán Jedličkův průvodce Prachovskými skalami.

V oblasti Hruboskalska se používala sedmistupňová škála obtižnosti přelezů a až v 1942 došlo k rozšíření stupnice po výstupu J. Smítky Kouřovou cestou na Daliborku. J. Smítka doplnil stupeň VII písmenem b. Později byl stupeň obtížnosti VII rozlišen na VIIa, VIIb a VIIc.

Dne 29. 4. 1972 bylo v Sedmihorkách na společné schůzi zástupců všech tř́i vrcholových komisí (oblast Labské pískovce, oblast Český ráj a oblast Teplicko-adršpašské skály) schváleno konečné znění „Jednotné pískovcové klasifikace“ (JPK) a způsob určování jednotlivých stupňů obtížnosti. V JPK (1972) je stanoveno:

1. Cestu hodnotíme podle nejtěžšího úseku-místa, za predpokladu, že tento úsek-místo je pro danou cestu typický.

2. Přitom přihlizzíme $k$ četnosti těžkých míst a jejich délce, přičemž je dovoleno nejvýše o jeden stupeň klasifikaci úmyslnè snížit nebo povýšit v následujících prrípadech:

a) krátkou cestu s jedním těžkým mistem lze klasifikovat o stupeň níže než nejtěžší místo, protože únava neprichází v úvahu;

b) dlouhou cestu fyzicky namáhavou lze klasifikovat o stupeñ výše, protože únavou z lezení se obtižnosti zákonitě zvyšují. Napřiklad delši kolmá až převislá stěna s charakteristickými prvky VI. stupně se označi VII. stupněm.

3. Vytipujeme vzorové cesty klasifikace I-VIIc v každé oblasti, podle nichž srovnáním určíme klasifikaci ostatních cest. Vzorové cesty v hledané oblasti budou uvedeny v záhlaví každého dílu průvodce.

4. Klasifikace nejtěžších cest VIIb a VIIc určíme srovnáním s jinou skupinou skal v tradiční oblasti, např v Českém ráji srovnáním Hruboskalska s Prachovem a Mužským. U ostatních lehčích cest postupujeme směrem dolü. 
Tab. 2: Jednotné vyjádření pískovcové klasifikace (JPK)

\begin{tabular}{|l|l|}
\hline Stupeň obtížnosti & Popis obtížnosti \\
\hline I - velmi snadné & rukou je třeba jen k udržení rovnováhy \\
\hline II - snadné & použití rukou k výstupu je již nezbytné \\
\hline III - lehké & zdolá lezec bez speciálního tréninku \\
\hline IV - mírně těžké & charakterizován krátkou námahou cestou \\
\hline V - středně těžké & delší exponovaný výstup s technickými prvky \\
\hline VI - těžké & stupeň obtižný i pro trénovaného \\
\hline VII - velmi těžké & dlouhý, technický, fyzicky náročný výstup vyžadující specializaci \\
\hline VIIb - neobyčejně těžké & definice VII + jedno místo krajně těžké \\
\hline VIIc - krajně těžké & lezení na hranici současných možností \\
\hline
\end{tabular}

Mezistupňủ se v této klasifikaci nepouživalo. Místo mezistupňủ se použivaly pomocné výrazy, které jsou však všeobecně závazné, např.: namáhavé - pro stupně obtižnosti IV až VII; krajně namáhavé - stupně obtížnosti VIIb a VIIc; exponované - užívá se pro všechny stupně obtížnosti.

Od roku 1976 byly v Sasku používány ještě další dva stupně - stupeň VIId a VIIe. Podle návrhu Berta Arnolda byla použivána k ohodnocení obtížnosti cest i obtížnost VIIIa a výše. V roce 1980 byl v Sasku zaveden zcela oficiálně VIII., IX. a X. stupeň obtížnosti, rozdělený mezistupni a, b, c.

Tab. 3: Porovnání obtížností pískovcových stupnic ve vyšších stupních obtížnosti (dle Šajnohy, 1990)

\begin{tabular}{|c|c|c|c|c|c|}
\hline JPK & Policko & $\begin{array}{c}\text { Labsko } \\
\text { (neoficiální) }\end{array}$ & $\begin{array}{c}\text { NDR } \\
\text { (do 1980) }\end{array}$ & $\begin{array}{c}\text { NDR } \\
\text { (Arnold) }\end{array}$ & UIAA \\
\hline VI & VI & VI & VIIa & VIIa & V+ \\
\hline VII & VII & VII & VIIb & VIIb & VI- \\
\hline & & & & & VI \\
\hline VIIb & VIIa & VIIb & VIIc & VIIc & VI+ \\
\hline & VIIb & VIIc & VIId & VIIIa & VII - \\
\hline VIIc & & VIII & & VIIIb & VII \\
\hline & VIIc & VIIIb & & VIIIc & VII+ \\
\hline & & VIIIc & VIII & IXa & VIII- \\
\hline & & & & IXb & VIII \\
\hline & & & & IXc & VIII+ \\
\hline & & & & Xa & IX- \\
\hline & & & & Xb & IX \\
\hline & & & & & IX+ \\
\hline
\end{tabular}

\section{SOUČASNÉ STUPNICE OBTÍŽNOSTI VOLNÉHO LEZENÍ}

V současné době se ve světě použivá několik stupnic obtížnosti, které prošly mnohaletým vývojem.

Všechny stupnice obtížnosti jsou pouze subjektivní škálou, která přibližně naznačuje, jaké obtíže lze očekávat při výstupu zvolenou cestou. Stanovení obtížnosti je ponecháno autorovi cesty či prvovýstupci, který cestu ohodnotí. Tím se škály liší oblast od oblasti, ale také podle prvovýstupce. 
Pro skalní lezení, volné lezení resp. sportovní lezení se použivá několik navzájem porovnatelných stupnic:

1. UIAA - v roce 1979 schválila UIAA stupnici obtížnosti, která je dodnes používaná jak v nevelehorských terénech, tak i v horách. Vychází z Welzbachovy šestiškálové stupnice, která byla v uvedené době doplněna o sedmý stupeň. Označuje se římskými číslicemi doplněné minusem nebo plusem:

stupeň I - malé obtíže - nejjednodušší forma skalního lezení, při které je nutné používat pro udržení rovnováhy ruce;

stupeň II - mírné obtíže - lezení, při kterém je nutné použivat pravidlo tří pevných bodů;

stupeň III - střední obtíže - skutečné lezení, při kterém je nutno použít ruce k výstupu; terén je položený, kolmý;

stupeň IV - velké obtiže - při tomto stupni začíná „ostřejši““ lezení; vyžaduje již určité lezecké zkušenosti;

stupeň V - velmi velké obtíže - obtížné lezení, které klade zvýšené požadavky na lezeckou techniku a kondiční připravenost, nutné určité lezecké zkušenosti;

stupeň VI - nesmírně velké obtíže - zvyšování nároků oproti stupni V;

stupeň VII - neobyčejně obtížné - stupeň obtížnosti dosažitelný pouze pravidelným tréninkem; stupeň VIII - více neobyčejně obtížné - stupeň obtižnosti, ve kterém jsou vystupňovány obtíže, přelezení je možné pouze pravidelným speciálním tréninkem;

stupeň IX - přelezy možné pouze po dlouhodobých speciálních trénincích a mnohdy po nacvičení pohybových sekvencí lezecké cesty;

stupeň X - narůstání lezeckých obtíží přelezů oproti stupni IX;

stupeň XI - extrémně obtížné - přelez cesty je možný pouze po dlouhodobém nácviku pohybových sekvencí a po speciálním tréninku zaměřeným pouze na danou lezeckou cestu.

V současné době končí stupnice stupněm XII-.

2. Francouzská - používaná hlavně na sportovně zajištěných cestách vápencových oblastí Francie a Itálie. Stupnice má otevřený konec. Do stupně 6 je bez dalšího označení. Od šestého stupně se používá s doplňkovým označením a, $\mathrm{a}^{+}, \mathrm{b}, \mathrm{b}+, \mathrm{c}, \mathrm{c}+$. V současné době končí stupněm $9 \mathrm{c}$. Za posunutí hranice obtížnosti na uvedený stupeň vděčíme českému lezci Adamu Ondrovi, který počátkem září 2017 uskutečnil svůj Project Hard v norském Flatangeru.

3. Americká YDS (Yosemite Decimal System) - stupnice vznikla modifikací Welzbachovy stupnice v roce 1937 jako Sierra Club System:

tríída 1 - chůze;

třída 2 - jednoduché přelézání skalních útvarů s občasným použitím rukou;

třída 3 - jednoduché lezení; lezecké lano je součástí výbavy pro túru;

třída 4 - jednoduché lezení, často exponované úseky, lano je často použito pro postupové jištění; pro postupové jištění je použiváno prírodních útvarů;

trrída 5 - začátek skutečného lezení.

V roce 1950 byla stupnice rozšířena o popis stupňů skutečného lezení. Systém rozděluje terén podle technické a psychické obtížnosti:

stupně 5.0-5.7 - velmi lehké lezení pro zkušené lezce;

stupně 5.8-5.9 - prŕijemné lezení za použití specifických technik;

stupeň 5.10 - počátek „skutečného“ lezení;

stupně 5.11-5.15 - stupňování lezeckých obtíží.

4. NCCS (National Climbing Classification System) - hodnocení výstupů ve velkých stěnách je často doplněno stupnicí vyvinutou ve Spojených státech NCCS. Dělí se na šest stupňů. Jednotlivé stupně jsou popisovány: 
stupeň I - délka lezecké cesty nepřesahuje několik hodin, občasné lezecké obtíže;

stupeň II - cesta trvající minimálně půl dne, občasné technické obtíže;

stupeň III - cesta vyžadující jeden den, velký díl technických problémů;

stupeň IV - cesta vyžadující jeden celý den, volné lezení není lehčí než 5.7;

stupeň V - cesta trvající jeden až dva dny, volné lezení je obvykle 5.8 nebo těžší;

stupeň VI - několikadenní lezecká cesta s obtížnými lezeckými úseky volného nebo technického lezení.

V lezeckých průvodcích se pak objevuje hodnocení obtížnosti složené z nejobtížnějšího úseku volného lezení např. 5.11b. Druhá informace je o délce výstupu např. VI.

5. Saská stupnice (popř. pískovcová) - stupnice vycházející ze staré uzavřené pískovcové klasifikace. V 80. letech 20.stol rozšířena na další stupně VIII, IX, X, XI a nejnověji na stupeň XII. Stupně jsou rozlišeny písmeny $\mathrm{a}, \mathrm{b}, \mathrm{c}$.

Tab. 4: Srovnávací tabulka obtížností

\begin{tabular}{|c|c|c|c|}
\hline UIAA & FR & YDS & Saská \\
\hline II & III & 5.5 & IV \\
\hline IV & IV & 5.6 & $\mathrm{~V}$ \\
\hline $\mathrm{V}$ & 5 & 5.7 & $\mathrm{VI}$ \\
\hline $\mathrm{V}+$ & \multirow{2}{*}{$5+$} & 58 & VIIa \\
\hline VI- & & \multirow{2}{*}{5.9} & VIIb \\
\hline VI & \multirow{2}{*}{$6 a$} & & \multirow{2}{*}{ VIIc } \\
\hline VI+ & & $5.10 \mathrm{a}$ & \\
\hline VII- & \multirow{2}{*}{$6 \mathrm{~b}$} & $5.10 \mathrm{~b}$ & VIIIa \\
\hline VII & & $5.10 \mathrm{c}$ & VIIIb \\
\hline VII + & $6 c$ & $5.10 \mathrm{~d}$ & VIIIc \\
\hline VIII- & \multirow{2}{*}{$7 a$} & $5.11 \mathrm{a}$ & IXa \\
\hline VIII & & $511 \mathrm{~h}$ & $\mathrm{IXb}$ \\
\hline VIII+ & $7 \mathrm{ab}$ & $5.11 \mathrm{c}$ & \multirow{2}{*}{ IXc } \\
\hline VIII+/IX- & $7 b$ & $5.11 \mathrm{~d}$ & \\
\hline IX- & $7 b+$ & $5.12 \mathrm{a}$ & \multirow{2}{*}{$\mathrm{Xa}$} \\
\hline IX-/IX & $7 \mathrm{bc}$ & $5.12 \mathrm{~b}$ & \\
\hline IX & $7 \mathrm{c}$ & $5.12 \mathrm{c}$ & \multirow{3}{*}{$\mathrm{Xb}$} \\
\hline IX/IX+ & $7 \mathrm{c}+$ & $5.12 \mathrm{~d}$ & \\
\hline $\mathrm{IX}+$ & $7 \mathrm{c}+/ 8 \mathrm{a}$ & $5.13 \mathrm{a}$ & \\
\hline $\mathrm{IX}+/ \mathrm{X}-$ & $8 \mathrm{a}$ & $5.13 b$ & \multirow{3}{*}{$\mathrm{Xc}$} \\
\hline $\mathrm{X}_{-}$ & $8 \mathrm{a}+$ & $5.13 \mathrm{c}$ & \\
\hline $\mathrm{X}-/ \mathrm{X}$ & $8 \mathrm{ab}$ & $5.13 \mathrm{~d}$ & \\
\hline $\mathrm{X}$ & $8 \mathrm{~b}$ & $5.14 \mathrm{a}$ & XIa \\
\hline $\mathrm{X} / \mathrm{X}+$ & $8 \mathrm{~b}+$ & $5.14 b$ & $\mathrm{XIb}$ \\
\hline $\mathrm{X}+$ & $8 \mathrm{c}$ & $5.14 \mathrm{c}$ & XIc \\
\hline XI & $8 \mathrm{c}+$ & $5.14 \mathrm{~d}$ & XII \\
\hline $\mathrm{XI}+$ & $9 a$ & & \\
\hline XII- & $9 b$ & & \\
\hline & $9 \mathrm{c}$ & & \\
\hline
\end{tabular}


Horolezectví a sportovní lezení prožívá v současné době bouřlivý rozvoj. Obrovský nárůst popularity je zřetelný u sportovního a soutěžního lezení. Soutěžní lezení bylo po dlouhých peripetiích zařazeno na program letních olympijských her. Narůstá počet stěn jak v České republice, tak ve světě. (Klauz 2013).

Hodnocení výkonu v lezení na pískovcích, sportovním lezení a horách je otázkou nekončících diskuzí, které se v lezecké veřejnosti periodicky opakují. K vlastním stupnicím je pak nutno přidat styl přelezu, ke kterému jsme se v článku nevyjadřovali.

Stupnice obtížnosti, jak již bylo napsáno, je subjektivní pohled autora cesty a jeho blízkého okolí. Tento subjektivní dojem z lezecké cesty by měl být co nejvíce objektivizován v rámci lezeckých cest $v$ dané lokalitě. Pískovcové oblasti použivaly do konce 80 . a na začátku 90. let minulého století stupnici JPK, která byla shora uzavřená a její nejvyšší obtížnost byla zaznamenána jako VII c. Snaha o udržení shora ohraničené stupnice skončila na počátku 90. let, kdy se zcela prrirozeně přistoupilo k otevření stupnice a jejímu sjednocení se stupnicí Saskou, ve které se v té době objevovalo hodnocení X b. V první polovině devadesátých let se uskutečnilo překlasifikování lezeckých cest $\mathrm{v}$ oblasti Teplických skal, kde se původní stupnice JPK přetvořila $\mathrm{v}$ stupnici UIAA, ale po několika málo letech, resp. s vydáním dalšího průvodce, se stupnice vrátila $\mathrm{k}$ pískovcovému hodnocení a pro hodnocení cest byla použita stupnice Saská. Tuto snahu můžeme zaznamenat i ve slovenských Tatrách, kde úvahy o klasifikování také byly. Snahy o překlasifikování byly podloženy narůstající úrovní lezecké dovednosti. Ukázaly se jako marné, protože lezecká komunita si vytváří hodnocení sama a zásah vyšší moci byl vždy zbytečný.

Dalším problémem je srovnání úrovně obtižnosti. V textu sice předkládáme tabulku, která je u lezců notoricky známá, ale jedná se pouze o nástin. Zvláště pak u porovnání Saské či JPK stupnice se stupnicí UIAA nebo Francouzskou je velmi zavádějící vzhledem k systému jištění na různých typech skal. S nárůstem tréninkových možností na umělých lezeckých stěnách je u lezců patrný výrazný rozdíl mezi fyzickou připraveností pro přelezy sportovních cest na vápencových skalách a lezení na pískovcích. K tomu můžeme použít citát jednoho z předních českých lezců 90 . let 20. stol. Takže i když jsem vylezl dobře zajištěnou devitku s prstem v nose, na spoře odjištěné šestce jsem se zatraceně nadřel. Výsledek? Dojmy z cest rovnocenné, šestku jsem si rozhodně pamatoval déle." (Šilhán, 2001, s. 210-211).

Nejistota při pískovcovém lezení je jednou z krás tradičního horolezectví. Při tomto způsobu lezení nezaniká dobrodružství, které bylo od počátku velmi důležitou součástí výkonu. Historicky je nutno podotknout, že naši předkové měli daleko větší úctu ke skálám a lezeckým cestám. Pískovcové lezení a jeho hodnocení představuje tradiční hodnotu, specifikum, které přetrvává přibližně 150 let. V současné době, kdy lezení velmi silně ovlivňuje množství lezců holdujících lezení na umělých lezeckých stěnách, které jsou přeplněné postupovým jišsěním, je nutné poukázat na um a odvahu našich předků, kteří přelézali velmi obtížné cesty s minimem jištění. Při použíání jiného systému jištění by pískovcové lezení ztratilo svou jedinečnost, kterou respektuje celý lezecký „svět“.

K vlastním stupnicím pro pískovcové skaly se mnoho lezců vyjadřuje s respektem a hovoří o nutnosti dodržovat zvyklosti v dané lokalitě. Jedna z výrazných osobností Milan Krauskopf z Dolního Žlebu se podělil o svoje zkušenosti s klasifikací na písku.

„Byl jsem s člověkem, který začínal lézt ve skalách, chci mu ukázat rozdíl mezi čtyřkou a sedmičkou, kterou jsme přelezli, nastoupím do ní a nepřelezu jí. Klasifikaci cesty navrhuje prvovýstupce, dál by se o tom mělo někde mluvit a zhodnotit, jestli to odpovídá, prípadně navrhnout jiné ohodnocení (třeba dal VII, a to je blbost, to by měla být třeba). Je dobré, aby tyto poznámky byly v průvodci. Např. v Tisé se mi může stát, že polezu šestku, vi̊bec nevylezu a navíc si rozbiju hubu. Problém je, že stupnice byla uzavřená a končila VIIe, pak se stupnice otevřela, ale nedošlo k překlasifikování. Bylo by to potřeba u spousty cest. Nikdo u nás se změnou klasifikace nepracuje. Neustále se vydávají průvodce. Problém 
např. VI na Vojtěcha, významná cesta v Labáku. Nezajistís se tam do 15 m nad zemí a pád je do šutrů. Cestu bych přklasifikoval. V Německu by odpovídala tak VII-VIIb. Klasifikace v Labáku je známá tím, že je až o dva stupně těžši než v Německu. Nevadilo by tedy uvádèt: u nás lezu VIIa, v Německu VIIIc. Cesty tu mezi sebou nejsou srovnané, stejné stupně obtižnosti se tu dost liší. Když jsme dělali cesty, taky jsme se snažili, ale dávali jsme obtížnosti podle toho, co jsme méli vylezené."

Petr Vlaštovička ml. se vyjadřuje následovně: „Klasifikace je v Čechách celkem jednotná a dle mého koresponduje s klasifikací v Německu. Ale samozřejmě v každé oblasti existují výjimky, o kterých se většinou ví, ale z tradice se to nechává být. Také lezení v každé oblasti má svá specifika, takže sice lezu IXc v Labáku, ale v Ádru už ne. “

Nejmladší z trojice dotazovaných Tomáš Sobotka k pískovcovým stupnicím uvádí: „Klasifikace je něco, čeho se můžěs približně chytit. Jedná se o celkovou formu, ta je celkem stabilní, ale je tu dalších $x$ věcí, které tě ovlivňují. Jedna cesta se ti nepoleze nikdy stejně. $90 \%$ obtižnosti si člověk dělá sám $v$ hlavě. Pro mě je klasifikace měritelná na vápně. Já už ji pomalu něreším, protože se na ní nejsem schopný shodnout ani s kamarády. “

Snahy o kvantifikaci lezeckého výkonu jsou dokumentovány v několika výzkumech (Chaloupský 2008; Draper 2011). Každý z autorů předložil jednotnou stupnici hodnocení výkonu, která má sloužit jako měřítko lezeckého výkonu. Jedná se pouze o teoretické měřítko, které není pro pískovcové lezení relevantní. Chaloupský (2008) se ve svém výzkumu zaměřil na sjednocení klasifikace a na dokumentování rozdílné úrovně přelezů při pískovcovém lezení a lezení na sportovně zajištěných cestách. Ze šetření vyplynul fakt o přelézání cest nižší obtížnosti na pískovcových skalách vzhledem k systému jištění. Tento fakt však primárně neznamená nižší výkon s ohledem na psychickou náročnost pískovcového lezení. Snahy o sjednocení stupnic se naštěstí odehrávají pouze na teoretické úrovni, protože každá stupnice výkonu v lezení má svá specifika, jasný vztah $\mathrm{k}$ dané lokalitě, systému jištění, tradici, a proto lze stupnice srovnávat jenom informativně.

\section{ZÁVĚR}

Pískaření (lezení na pískovcových skalách) je specifickým typem lezení, které můžeme nazvat tradiční lezení, v některých oblastech i horolezectvím. Hodnocení výkonu na těchto typech skal je velmi obtížné a stupnici výkonu nelze srovnávat se stupnicemi, které se používají na vápenci nebo žule. Způsob jištění na těchto skalách je velmi odlišný a postupové jistící body jsou umístěny mnohem bliže $\mathrm{k}$ sobě, než je tomu na pískovcích. V mnohých pískovcových oblastech jsou dodržovány a ctěny tradiční hodnoty pískaření - tj. málo jistících bodů (kruhů) a možnost dojištovat lezeckou cestu pouze smyčkami. V některých oblastech (levý břeh Labe ve Hřensku) je zajištěn velmi podobně, jako je tomu na vápencových skalách. Při tomto stylu lezení je potlačeno dobrodružství, které by mělo být součástí lezení. Pískovcové lezení v Čechách a sousedním Sasku je jedinečné jak z hlediska skalních tvarů, tak způsobem lezení a jištění. $V$ tomto směru je velmi žádoucí ctít tradice a sledovat pozvolné zvyšování obtížnosti přelezů při zachování tradičního lezení (horolezectví), které obdivuje celý svět. „Mnohdy nás mají zahraniční lezci za blázny.“

\section{Reference}

Bauše, R. O. (1948). Skalní věže na Mužském - horolezecký průvodce. Praha: Ministerstvo školství a osvěty.

Dieška, I., Širl, V.(1989). Horolezectví zblízka. Praha: Olympia, 1989. s. 444.

Dieška, I. a kol. (1987). Ontologické problémy horolezectví - Prednášky zo seminárnej časti Memorialu zaslužilého majstra športu Ing. Jozefa Psotku. Bratislava: SÚV ČSZTV.

Draper, N., Hejtmánek, P., Homolka, M. \& Sochor, J., (1996). Hruboskalsko. 1. díl. Jablonec nad Nisou: Hejtmánek. 
Jedlička, M. (1961). Pískovcové skály v Čechách - horolezecký průvodce (1). Český ráj. Praha: Sportovní a turistické nakladatelství.

Choudovský, K. (1903). Sport. Přednáška pronesená v Alpském družstvu českém. Praha: J. Otto.

Chaloupský, D. (2008). Úroveň maximálních výkonů horolezců v závislosti na rozdílných specifických podmínkách bezpečnosti lezení. Nepublikovaná disertační práce. Brno. FSS MU.

Janeba, J. (1934). Horolezecká cvičení v Prachovských skalách. Praha: Klub alpistů Čsl.

Kauschka, R. (1924). Wandern und klettern: Ein Heimatbuch für Bergfreunde. Reichenberg: Paul Sollors' Nachf.

Kittler, A. (2008). Rudolf Kauschka: 1883-1960: eine biographische Studie über den kletternden Lyriker des Isergebirges, den Rodelmeister und Alpinisten. Dresden: Albrecht Kittler.

Klaus, M. (2013). Socioekonomický profil lezců na umělých stěnách v Praze. Nepublikovaná diplomová práce. UK FTVS v Praze. Lisák, P. (1992). Teplické skály - horolezecký průvodce. Náchod: Juko.

Matouš, M. (2004). Historie pískovcového horolezectvív Českém ráji od začátku 20. století do konce osmdesátých let 20. století. Nepublikovaná diplomová práce. UK FTVS v Praze,

Sýkora B. (2004). Pískaři. Náchod: Juko

Šajnoha, M. et al. (1990). Horolezectvo - učebnica pre školenie cvičitelov. Bratislava: Šport

Šilhán, F. (2001) Cesta do hor. Brno: Montana.

Šmíd, M. (1991). Ze života horolezce. Praha: Olympia.

Rubín, J., Balatka, B., et al. (1986). Atlas skalních, zemních a půdních tvarů. Praha: Academia.

Vomáčko, L., Baláš, J. \& Vojtík, P. (2006). Terminologická poznámka k lezeckému a horolezeckému názvosloví. In Sborník Semináře VŠ učitelů lezení a horolezectví. Praha: UK FTVS.

Vomáčko, L. \& Boštíková, S. (2008). Lezení na umělých stěnách. Praha, Grada.

Vomáčko, L. (2008). K struktuře výkonu ve sportovním lezenív souvislosti s obecnými a speciálními testy pohybové výkonnosti a osobnostního profilu lezce. Nepublikovaná disertační práce. Praha, UK FTVS v Praze.

Zak, H. (1996). Rock Stars - hvězdy volného lezení. Vsetín: Trango.

\section{Informanti:}

Milan Krauskopf, Tomáš Sobotka, Petr Laštovička ml., Igor Koller Archív ČHS

\section{Korespondující autor:}

Mgr. Ladislav Vomáčko, Ph.D.

svomacko@ftvs.cuni.cz

tel: 220172017

Univerzita Karlova

Fakulta tělesné výchovy a sportu

José Martího 31

Praha 6 